\title{
Alien Fish Species in the Mbô Floodplain Rivers in Cameroon
}

\author{
Claudine Tekounegning Tiogué $\left(\mathbb{D},{ }^{1}\right.$ David Nguenga, ${ }^{2}$ Minette Eyango Tomedi-Tabi, ${ }^{3}$ \\ Joseph Tekwombuo, ${ }^{4}$ Guegang Tekou, ${ }^{3}$ and Joseph Tchoumboué ${ }^{4}$ \\ ${ }^{1}$ Laboratory of Applied Ichthyology and Hydrobiology, School of Wood, Water and Natural Resources (Ebolowa Antenna), \\ Faculty of Agronomy and Agricultural Sciences, University of Dschang, P. O. Box 786, Ebolowa, Cameroon \\ ${ }^{2}$ Regional Center MINRESI/CRRI-West, Ministry of Scientific and Technical Research, P. O. Box 665, Bafoussam, Cameroon \\ ${ }^{3}$ Department of Aquaculture, Institute of Fisheries and Aquatic Sciences at Yabassi, University of Douala, \\ P. O. Box 2701, Douala, Cameroon \\ ${ }^{4}$ Laboratory of Applied Ichthyology and Hydrobiology, Department of Animal Productions, \\ Faculty of Agronomy and Agricultural Sciences, University of Dschang, P. O. Box 222, Dschang, Cameroon
}

Correspondence should be addressed to Claudine Tekounegning Tiogué; claudine.tiogue@univ-dschang.org

Received 21 February 2018; Accepted 15 July 2018; Published 13 August 2018

Academic Editor: Franck Courchamp

Copyright (C) 2018 Claudine Tekounegning Tiogué et al. This is an open access article distributed under the Creative Commons Attribution License, which permits unrestricted use, distribution, and reproduction in any medium, provided the original work is properly cited.

\begin{abstract}
The aim of this study was to identify different alien fish species introduced in the Mbô Floodplain (MF) Rivers in Cameroon and to study their life-history traits. For this purpose, a total number of 237 fishes with a total length (TL) of $24.50 \pm 5.97 \mathrm{~cm}$ and total weight of $199.50 \pm 106.78 \mathrm{~g}$ collected by traditional fishing gears were used for taxonomic identification. Four species grouped into three families were identified: Clariidae (Clarias gariepinus), Cichlidae (Oreochromis niloticus and Tilapia cameronensis), and Channidae (Parachanna obscura). There are two types of fish introduction: accidental introduction and intentional transfer. All fish species collected and examined were of large sizes (TL $>25 \mathrm{~cm}$ ). The regression coefficient b of the length-weight relationship ranged from 3.00 (C. gariepinus) to 3.37 (T. cameronensis) $(3.18 \pm 0.17$ ). Fish species showed a monthly and seasonal fluctuation in abundance in number of individuals. Alien fish species in the Mbô Floodplain showed two types of somatic growth: isometric and positive allometric. $75 \%$ of overall alien fish species were established and they recorded a mean K factor of $0.70 \pm 0.40$. Only $25.00 \%$ of the sampled species had more females than males.
\end{abstract}

\section{Introduction}

An alien species or alien genotype is a species, subspecies, or lower taxon occurring as a result of human action in an area or ecosystem in which it is not native [1]. Introduced species concern any population, species, or race intentionally or accidentally transported and released by man into an environment outside its native range [2-6]. The introduction of alien fish species in freshwater is a common and old practice in many parts of the world [7]. Exotic fishes have become accidentally introduced outside their natural range by escaping from captivity, natural diffusion, and accidental transportation with other species and more rarely as stowaways in the ballast-water tanks of transoceanic vessels $[8,9]$. The purposes for which species have been intentionally introduced are various: they can be a means of enriching poor settings in species due to their geological history $[10,11]$, they are also practiced to remedy the depletion of indigenous stocks subject to overfishing [12], and they can be used for the development of recreational activities such as sport fishing [13] and for the market of ornamental species. Nonnative fish species have also been used in biological control and biomanipulation [14, 15]. The uses of exotic fish species to control unwanted aquatic organisms were concerned principally with the attempted eradication of mosquito larvae. Control of mosquito larvae by small larvivorous fish species (e.g., Poecilia latipinna, Poecilia reticulata, and Gambusia affinis) is highly effective [16]. The introduction of molluskivorous (Astatoreochromis alluaudi) fishes has been proposed for controlling the aquatic snail vector of Schistosomiasis (bilharzia) [17]. Other fish species such as Mylopharyngodon piceus and more recently Heterotis 
niloticus have been reported to feed widely on gastropod mollusks [18].

Fish introduced or transferred also contributed to the change in the functioning of aquatic ecosystems and in the control or eradication of the aquatic weed. This is the case of grass carp Ctenopharyngodon idella and Hypophthalmichthys molitrix that have, respectively, been used successfully for the elimination of aquatic weed and algal blooms in Europe [14, 19]. In most African countries, introductions have been made to produce high quality fish protein, alleviate poverty and hunger, and provide employment, control disease vectors, and weeds [20-22]. In the FAO database, these different purposes have been grouped into three main classes: aquaculture development, biological control and capture, and sports fisheries $[14,23,24]$.

Of the 478 fishes introduced into Africa for improving objectives fishing (commercial and recreational) by supplementation of natural populations and biological control (e.g., a few species were introduced in Lower Guinea as biological control agents, such as Astatoreochromis alluaudi Pellegrin, 1904, for snail control and most probably some killifishes (Poeciliidae) for mosquito control [14, 24]; 212 freshwater fish species were for aquaculture purposes and only $33(16 \%)$ have enabled the development of an aquaculture activity $(>10$ t/year) [25]. Of these 33 fish species, $10(30 \%)$ concern the common carp from Asia and Europe and 7 (21\%) concern the Nil tilapia from other African countries [14]. In Cameroon, all aquaculture species are exotic or translocated. These include the common carp (Cyprinus carpio), the Nile tilapia (Oreochromis niloticus), the African catfishes (Clarias gariepinus and Heterobranchus longifilis), the Arapaimidae Heterotis niloticus, the African snakehead fish Parachanna obscura, and Tilapia cameronensis [26-32]. To our knowledge, with the exception of the Arapaimid Heterotis niloticus in the river Nyong $[9,33]$, the status and bioecology of species introduced or transferred into Cameroonian's Rivers have not been studied.

The Mbô Floodplain of Cameroon has many important rivers whose fishery resources play a significant role in the economy and food habits of the local populations [34]. This area is subject to many introductions and transfers of fish species [24]. This situation raises questions on the origin (types of introductions), number and populational parameters of alien fish species in this area. To answer these questions, the following aims were defined: to identify different alien fish species, to determine their origin, to estimate their monthly frequency of occurrence in the captures, and to evaluate their ability in terms of the length-weight relationship, the condition factor $(\mathrm{K})$, and sex ratio in the Mbô Floodplain Rivers.

\section{Materials and Methods}

2.1. Study Area. The study was carried out from October 2014 to October 2015 in the Mbô Floodplain (MF) (NL 5 $10^{\prime}$, EL $9^{\circ} 50^{\prime}$; altitude: $700 \mathrm{~m}$ ) located in Cameroon (Central Africa). MF has a hot and humid climate characterised by two seasons: the dry season (mid-November to mid-March) with temperatures ranging between 18 and $30^{\circ} \mathrm{C}$ and relative humidity of $49 \%$; and the rainy season occurring the rest of the year with temperature that oscillate between 17 and $26^{\circ} \mathrm{C}$ [34]. The average rain fall is $1860 \mathrm{~mm}$ and the relative humidity is $98 \%$. The rivers of the MF come down from the Bambouto Mountain (Menoua River), from the Manengouba Massif (Nkam River and Black Water River), and several other streams (such as Metschie and Mfouri) from the Bana Massif [34]. All these rivers are drained by the Wouri River which flows into the Atlantic Ocean (Figure 1) [35].

2.2. Fish Samples. Fishes were surveyed once every month from October 2014 to October 2015. Fish species were collected from the fishermen. They were captured in the confluence zones of the rivers and the intermediate zones (nearest to the paved road), by means of traditional fishing gears (bow nets, hooks, and gill nets). Taxonomic identification was performed according to Stiassny et al. [24]. The origin and type of introduction of fish species were made from direct interviews with fishermen and with documents on this subject [24]. Fishes were counted; the relative abundance per species was estimated as the ratio of number of fish per species and the total number of fishes collected in the month. Then frequency of occurrence (FO) by month of a giving specie was calculated by the formula: FO (\%) = relative abundance $\mathrm{X} 100$. The total length was measured to the nearest $0.01 \mathrm{~cm}$. The body weight was measured using an electronic balance (Sartorius Competence) to the nearest $0.01 \mathrm{~g}$. The sex of each fish was determined by macroscopic examination of genital papilla, number of abdominal orifices, or the gonads after dissection.

The length-weight relationship (LWR) was determined by using the data on the measurement of length and weight of alien fish species. The LWR is expressed by using the equation: $\mathrm{W}=\mathrm{aL}^{\mathrm{b}}$, where $\mathrm{W}$ is body weight of the samples in $\mathrm{g}$, TL is length of the sample in $\mathrm{cm}$, a is constant (intercept), and $b$ is constant (slope of regression line) [36, 37].

2.3. Statistical Analysis. Data of the collected fish species through the study area were analysed using descriptive statistics (mean, standard deviation, and percentage). Sex ratio of the fish was studied using Chi-square root test $\left(\chi^{2}\right)$. The LWR equation was not transformed into a linear form; the equation was maintained as power, so in a curved line. The statistical significance of $\mathrm{r}^{2}$ (determination coefficient) was estimated and the $\mathrm{b}$ value tested using the $t$-test to verify if it was significantly different from the isometric $(b=3.0)$ [38]. Fulton's index is used for calculating the body condition in those cases when the growth is isometric $(b=3.0)$, once the isometry has been determined via statisticat test. If the growth is allometric (b different that 3.0), then the LeCren index $\mathrm{Kn}=\mathrm{W} / \mathrm{TL}^{\mathrm{b}} \mathrm{X} 100$ should be used, where $\mathrm{W}$ is weight $(\mathrm{g})$, TL is total length $(\mathrm{mm})$, and $\mathrm{b}$ is slope of the lengthweight relationship for the population examined [36]. The LeCren index condition factor $\mathrm{K}$ between fish species was compared using the general linear model. All the analyses were performed using SPSS 20.0 software at $\mathrm{P}=0.05$ and $\mathrm{P}$ $<0.01$ significance levels. Line graphs were done using Excel statistical package (2007). 


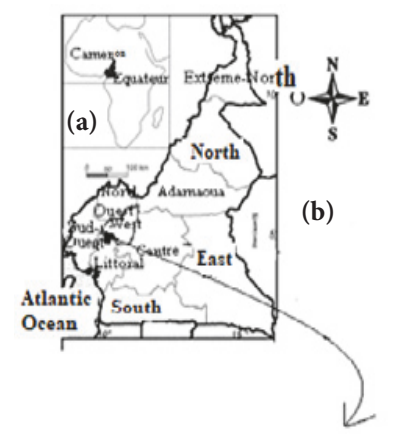

(b)

(c)
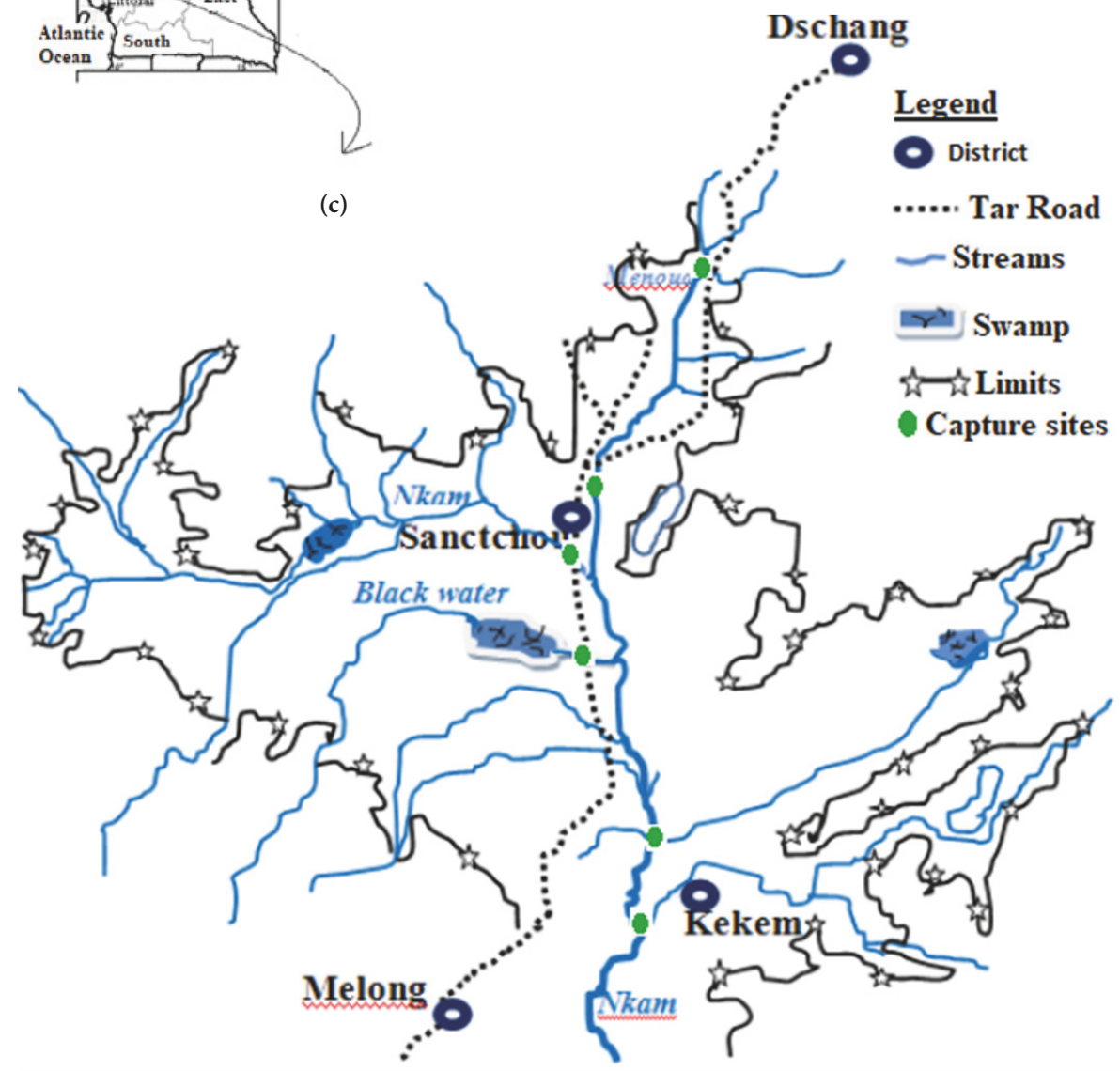

Figure 1: Study area: (a) Africa; (b) Cameroon; (c) hydrographic map of the Mbô Floodplain (adapted from [35]).

\section{Results}

3.1. Fish Species Introduced in the Mbô Floodplain. Four species belonging to three families were identified (Table 1): Clarias gariepinus (Clariidae), Oreochromis niloticus and Tilapia cameronensis (Cichlidae), and Parachanna obscura (Channidae). There are two modes of introductions in the Mbô Floodplain: accidental (Clarias gariepinus, Parachanna obscura, and Oreochromis niloticus) and transfer (Tilapia cameronensis). Depending on the relative abundance, three out of four of the alien fish species introduced in the Mbô Floodplain were established.

3.2. Morphometric Characteristics and Sex Ratio. A total of 237 fishes measuring 12 to $88.50 \mathrm{~cm}$ total length (TL) and 5.71 to $5250 \mathrm{~g}$ total body weight (W) (Table 1) were used for the analysis. The minimum sample size was 33 fishes (P. obscura), and the maximum was 78 fishes (Clarias gariepinus). The maximum size observed (MSO) for each fish species was greater than $25 \mathrm{~cm}$.
Sex ratio of the four alien fish species examined is shown in Table 1. Only $25 \%$ of overall species sampled had more females than males: 78 specimens sampled for C. gariepinus showed a sex ratio of $0.81 \mathrm{M}: 1 \mathrm{~F}$ in favour of females. The difference between the males and females was significant $\left(\chi^{2}\right.$, $\mathrm{P}<0.01)$ in this species. For P. obscura, O. niloticus, and T. cameronensis, the males were predominant over the females in this area with sex ratio of $1.09 \mathrm{M}: 1 \mathrm{~F}, 1.06 \mathrm{M}: 1 \mathrm{~F}$ and $1.14 \mathrm{M}: 1$ $\mathrm{F}$, respectively. However, this showed no significant difference $\left(\chi^{2}, \mathrm{P}=0.01\right)$ between the males and females.

3.3. Monthly and Seasonal Frequency Occurrence in the Catches. The monthly and seasonal frequency distributions of the various alien fish species are shown in Figure 2. The total number of fish species caught fluctuated in the Mbô Floodplain Rivers in all the months and seasons. C. gariepinus and $P$. obscura were absent from catches during three months of the year. However, C. gariepinus was relatively more abundant than all fish species, while P. obscura occurred feebly 


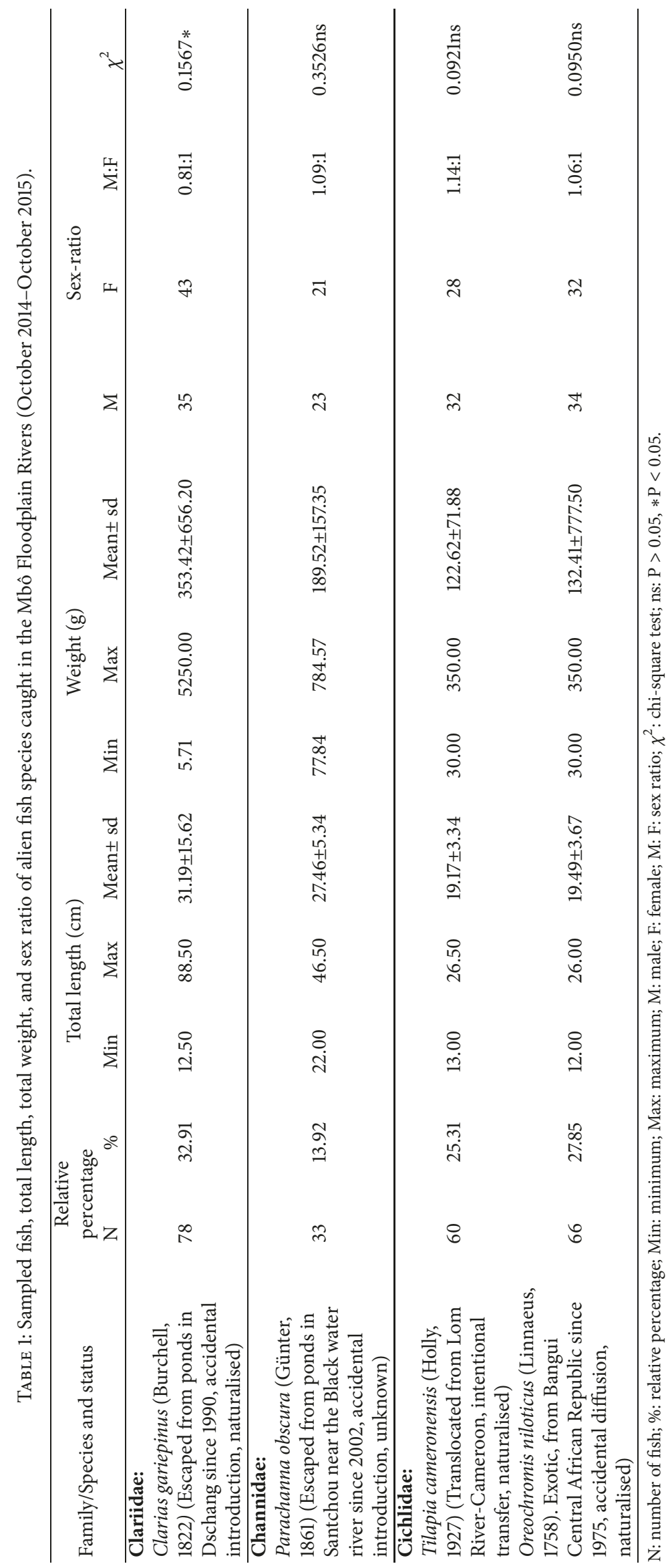


TABLE 2: Length-weight relationships parameters, growth type, and mean $\mathrm{K}$ factor of alien fish species caught in the Mbô Floodplain Rivers (October 2014-October 2015).

\begin{tabular}{|c|c|c|c|c|c|c|c|}
\hline \multirow{2}{*}{ Species } & \multicolumn{5}{|c|}{ LWR parameters } & \multirow{2}{*}{$\operatorname{Tg}$} & \multirow{2}{*}{ Mean K factor } \\
\hline & $\mathrm{N}$ & $r^{2}$ & $\mathrm{a}$ & $\mathrm{b}$ & ts & & \\
\hline Clarias gariepinus & 78 & 0.95 & $0.0062^{a}$ & $3.00^{b}$ & 0.020 & I & $0.674 \pm 0.300^{\mathrm{b}}$ \\
\hline Tilapia cameronensis & 60 & 0.92 & $0.0052^{\mathrm{a}}$ & $3.37^{\mathrm{a}}$ & 0.491 & $+\mathrm{A}$ & $0.523 \pm 0.083^{\mathrm{b}}$ \\
\hline Oreochromis niloticus & 66 & 0.90 & $0.0124^{\mathrm{a}}$ & $3.08^{\mathrm{b}}$ & 0.030 & I & $1.262 \pm 0.230^{\mathrm{a}}$ \\
\hline Parachanna obscura & 33 & 0.96 & $0.0034^{\mathrm{a}}$ & $3.26^{\mathrm{a}}$ & 0.417 & $+\mathrm{A}$ & $0.336 \pm 0.040^{\mathrm{b}}$ \\
\hline Total population & 237 & 0.93 & 0.0068 & 3.18 & 0.575 & $+\mathrm{A}$ & $0.700 \pm 0.400$ \\
\hline
\end{tabular}

$(\mathrm{a}$ and $\mathrm{b})$ superscript letters in the same column are significantly different $(\mathrm{P}=.01) ; \mathrm{N}$ : sample size; $\mathrm{r}^{2}$ : coefficient of determination; $\mathrm{a}$ and $\mathrm{b}=$ estimated parameters of the LWR (length-weight relationships); ts: Student's $t$-test; Tg: types of growth; I: isometric growth; +A: positive allometric growth; -A: negative allometric growth; \pm : standard deviation

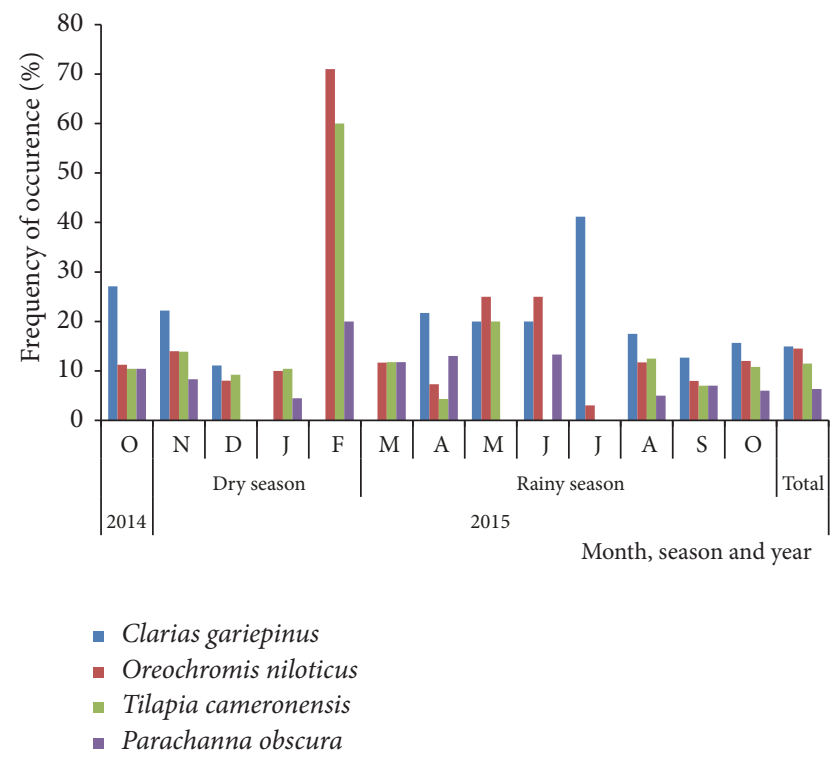

FIGURE 2: Monthly and seasonal frequency of occurrence in the catch of alien fish species from the Mbô Floodplain Rivers (October 2014-October 2015).

in the catches. C. gariepinus appears abundantly throughout the months of August to January. O. niloticus appears in all months of the year, followed by Tilapia cameronensis which was absent during two months (June and July). All fish species appeared on April and from August to November. Fishes were more abundant $\left(\chi^{2}, \mathrm{P}<0.05\right)$ in the rainy season catches compared to the dry season. Cichlids and the channid P. obscura were significantly (ANOVA I, $\mathrm{P}<0.05$ ) more abundant in February and almost absent in July where the silurid C. gariepinus has recorded the highest frequency occurrence (ANOVA I, P< 0. 05)

3.4. Length-Weight Relationships (LWR) and K Factor. The length-weight relationship characteristics and condition factor $(\mathrm{K})$ of the four species examined are presented in Table 2. The coefficient b ranged from 3.00 (C. gariepinus) to 3.37 (T. cameronensis) (mean $=3.18 \pm 0.17$ ). The coefficients of determination $\left(\mathrm{r}^{2}\right)$ of the LWR regressions ranged from 0.90 to 0.96 and were all highly significant (ANOVA
I, $\mathrm{P}<0.01)$. All length-weight relationships were highly significant (ANOVA I, $\mathrm{P}<0.01)$. Condition factor $(\mathrm{K})$ varied from 0.336 (Parachana obscura) to 1.262 (O. niloticus) (mean $=0.700 \pm 0.400)$. Except the cichlid O. niloticus which recorded a value of $K>1$, all fish species did not have good plumpness (ANOVA I, $\mathrm{P}<0.01$ ).

\section{Discussion}

4.1. Fish Species Introduced in the Mbô Floodplain. This study enables us not only to know the different alien fish species in this zone, but also to determine some of their populational parameters. Four alien species belonging to three families were identified. According to Brummett [39], the native range in Cameroon for the catfish Clarias gariepinus and tilapia Oreochromis niloticus is Benue River and Lake Chad and they were introduced to culture in Sanaga River Basin. The African catfish C. gariepinus was introduced accidentally in the Mbô Floodplain by escaping from ponds in Dschang since 1990. It is for this reason that in this area it is called by the fishermen "new catfish" versus endogenous catfish Clarias jaensis. The cichlid O. niloticus is a highly prolific and invasive species [39-42]. Introduced at Mount Cameroon watershed from the Central African Republic in 1975 [39], this species would have suffered from accidental diffusion upstream to the Mbô Floodplain Rivers.

Brummett [39] showed that the snakehead fish, Parachanna obscura, was nearly ubiquitous in Cameroon. It was introduced in the Mbô Floodplain accidentally by escaping from ponds in Santchou near the Black water river since 2002. Indeed, according to Lévêque [8], and Nguenga and Brummett [9], some species introduced for aquaculture escaped from fish ponds on the occasion of uncontrollable events such as extreme floods, while their presence in the natural environment was unwanted. Stiassny et al. [24] confirmed that Tilapia cameronensis is a Lower Guinea endemic, known from the Sanaga River and its tributaries in Cameroon. The species have been translocated from Lom River to Nkongsamba (Wouri River Bassin) and Yaoundé (Nyong River Bassin) with the objective to improve the local fisheries [24]. According to these authors, the great majority of introductions within Lower Guinea were originally made for aquacultural purposes as brood stock or forage or accidentally owing to misidentification of brood stocks. As 
elsewhere, many of these introductions subsequently found their way into the region's ecosystems $[24,43]$. It was the case of cichlid species (O. niloticus and Tilapia cameronensis) and Clariid Clarias gariepinus in the Mbô Floodplain Rivers. Then the Mbô Floodplain knows two kinds of fish introductions: accidental (C. gariepinus, O. niloticus, and P. obscura) and intentional (T. cameronensis).

4.2. Morphometric Characteristics and Sex Ratio. As the native fish species caught in the same zone, all alien fish species were of large sizes, indicative probably of a rapid growth and thus the reasons of their uses in enhancing fish production in the world [44]. The relative percentage of $C$. gariepinus and Cichlids recorded in this study is higher as those of [45] reported in Osinmo reservoir Ejigbo in Nigeria. Otherwise, these authors reported for P. obscura a relative percentage similar to those of our study.

Preponderance of female over the male for C. gariepinus in this study had been recorded in her endogen sister Clarias jaensis [44]. In our results, it was pointed out that in African water bodies it is common that the populations of male fish dominate because they generally present higher rapid growth than females without this representing a risk situation for fishery [46]. Sex ratio obtained in exogenous cichlid (O. niloticus and T. cameronensis) and Channid P.obscura in this study is similar to that recorded in the endogenous cichlid Tilapia camerunensis in the same study area [44]. In fact, the sex ratio is a characteristic of the species whose differences are sometimes related to the environment, capture sites, fish size, months, and seasons, Offem et al. [47].

4.3. Monthly and Seasonal Frequency Occurrence in the Catches. The results indicate that alien freshwater fish species showed a monthly and seasonal fluctuation in abundance in number of individuals. The fluctuation in abundance in terms of number also revealed a seasonal trend with a peak towards the rainy season and the mid-dry season for Clarias gariepinus or all seasons for other alien fishes (O. niloticus, T. cameronensis, and P. obscura). This fluctuation suggests that the seasonal changes in the habitat probably favoured the growth and development of the species, hence the large number in the field at this period of the year. Similar results have been also reported for the native fish species in the same area [44]. Then, seasonal changes could be associated with fishing vulnerability.

4.4. Length-Weight Relationships (LWR) and K Factor. Alien fish species caught in Mbô Floodplain Rivers have $b$ values equal to or higher than the hypothetical isometric value (b $=3$ ). The alien fish species in this area undergo two types of growth: isometric growth for C. gariepinus and O.niloticus and positive allometric growth for P. obscura and Tilapia cameronensis. These results corroborate those of Eagderi and Radkhah [48] recorded on Mosquitofish (Gambusia holbrooki) in three inland basins and those of Zamani et al. [49] of seven fish species of Totkabon River (southern Caspian Sea basin), Guilan in Iran. Thus, depending on these authors and on Montchowui et al. [50], these results show that, in the Mbô Floodplain Rivers, the growth in length is equal to the growth in weight in Clariidae family, while, in other exotic species, the fish gained more weight than length. Similar results were reported by Offem et al. [51] for forty-six important fishes species in a Tropical Flood River in Nigeria. These results are in accordance with the range of values for this parameter usually encountered in fish, between 2.0 and 4.0 or 2.5 and 4.0 according to Offem et al. Offem et al. [52] and Montchowui et al. [50] and Froese [37] confirmed that the $\mathrm{b}$ exponent should normally fall between 2.5 and 3.5. We consider our results to be an adequate estimation of the length-weight relationships, since the b parameter falls within the expected range of 2.5 to 3.5 .

In comparison, $\mathrm{b}$ values between the alien and native fish species in the Mbô Floodplain, Tiogué et al. [44], reported a negative allometric growth for Clarias jaensis, Labeobarbus batesii, Labeo camerunensis, and T. camerunensis. For fish species elsewhere, Montchwui et al. [49] reported an isometric growth for C. gariepinus and P. obscura in Lake Hlan in Benin. Coulibaly [52] and Aliko et al. [53] reported isometric growth, respectively, for Labeo senegalensis in Burkina Faso and for Distichodus rostratus in Ivory Coast. An isometric growth was reported for O. niloticus in Kenya and Burkina Faso; a negative allometric growth was reported for $C$. gariepinus in Soudan [52]. The same author reported a positive allometric growth for C. gariepinus, negative allometric growth for Heterotis niloticus, and isometric growth for Gymmarchus niloticus and Protopterus annectens in Burkina Faso. According to many authors [30, 37, 50, 53, 54], the causal factors of these differences were likely to be varied and include the number of specimens examined, their size range and reproductive stage, and the waters experiencing different climate and environmental variables. Condition factors of $\geq 1$ indicate a good level of feeding and proper environmental condition $[49,55]$; i.e., when condition factor value is lower, it means that the fish has attained an adverse condition [36]. In addition, the condition factors can be applied for comparing the condition, fatness or well-being of fish [37]. The cichlid $O$. niloticus recorded a $\mathrm{K}$ factor $>1$; thus he has a good overweight compared to other alien fishes. This value could be explained by the fact that other alien species should probably spend a lot of energy to develop adaptation strategies in their new habitat, and therefore they are in poor body. However, $O$. niloticus is an invasive species which quickly adapted into the plain Mbô Floodplain Rivers [24, 43] and even threaten to remove endogenous species $T$. camerunensis and the translocates species $T$. cameronenssis (which record a poor $\mathrm{K}$ factor $(0.523))$ that are becoming increasingly rare in the catches $[44,56]$. The channid (P. obscura) introduced in the plain recorded a very weak condition factor, thus confirming that this species is in foreign environment. However, more than O.niloticus, P. obscura is a very invasive species; his first specimen was captured far into the Mezoung River only two years after its introduction in the plain (Personal observation). His diet based on live prey [30] may eventually be a threat to the ichthyofaunal diversity of the plain as in the case of Lake Victoria in Kenya with the Nile perch Lates niloticus [54]. P. obscura is a large voracious predator, which feeds on a wide size range of different fish species. This species is often reared in polyculture with tilapia O. niloticus 
to control its excessive reproduction [30]. Introduced into any stream, $P$. obscura can cause in association with the overfishing and competition between different species and the reduction in the stocks of several endogenous species, as in many parts in Africa [57-59].

\section{Conclusion}

There are two types of fish introductions in the Mbô Floodplain: accidental introductions and intentional transfer. O.niloticus (Cichlidae) is the most frequent and C. gariepinus (Clariidae) is the most abundant alien species in the Mbô Floodplain streams. P. obscura (Channidae) and O. niloticus are invasive species which can be found anywhere. Three out of four of the alien fish species in the Mbô Floodplain were established. Alien fish species in the Mbô Floodplain shows two types of growth: isometric and positive allometric. Except the cichlid $O$. niloticus which recorded a condition factor $\mathrm{K}>$ 1 , all fish species had poor body condition. Only one out of the four alien species sampled had more females than males. All species were of large size, indicative of a rapid growth, as expected following their uses in aquaculture.

\section{Data Availability}

The authors and coauthors of this manuscript declare that the data collected from this work are available.

\section{Conflicts of Interest}

The authors declare that they have no conflicts of interest.

\section{Acknowledgments}

The authors are grateful to the four fishermen who helped collecting the data in the Mbô Floodplain.

\section{References}

[1] J. Mcneely, Ed., The great reshuffling: human dimensions of invasive alien species, IUCN, Gland, Switwerland, 2001.

[2] ICES, "Codes of practice and manual of procedures for consideration of introductions and transfers of marine and freshwater organisms," ICES Co-operative Research Report, vol. 159, no. 44, 1988.

[3] ICES, ICES Code of Practice on the Introductions and Transfers of Marine Organisms, International Council for the Exploration of the Sea, Copenhagen, Denmark, 1995.

[4] ICES, Code of Practice on the Introductions and Transfers of Marine Organisms, 2003, http://www.ices.dk/pubs/itmo.pdf.

[5] J. Lazard and L. Dabbadié, "Environmental impact of introduced alien species," Site Internet UNESCO EOLSS Encyclopedia, vol. 20, 2003, http://www.eolss.net/.

[6] M. D. Bartley and F. Marttin, Introduction of alien species/ strains and their impact on biodiversity, FAO Fisheries Department, Rome, Italy, 2004, http://www.worldfishcenter.orgPubsalien_speciespdf03.pdf.

[7] E. K. Balon, "About the oldest domesticates among fishes," Journal of Fish Biology, vol. 65, pp. 1-27, 2004.
[8] C. Lévêque, "Les introductions d'espèces dans les milieux naturels et leurs conséquences," in Les Poissons des Eaux Continentales Africaines: Diversité, Ecologie, Utilisation parl'Homme, C. Lévêque and D. Paugy, Eds., pp. 351-364, Editions IRD, Paris, 1999.

[9] D. Nguenga and R. Brummett, "Les facteurs d'adaptation et d'implantation du "Kanga", Heterotis niloticus (Cuvier, 1829), dans le fleuve Nyong (Cameroun)," International Journal of Biological and Chemical Sciences, vol. 4, no. 2, 2010.

[10] J. Lazard, Transferts de poisons et développement de la production piscicole, Exemple de trois pays d'Afrique subsaharienne, Rev Hydrobiol Trop 23, 251-265, 1990.

[11] T. Hesthagen and O. T. Sandlund, "Fish distribution in a mountain area in south-eastern Norway: Human introductions overrule natural immigration," Hydrobiologia, vol. 521, no. 1-3, pp. 49-59, 2004.

[12] C. Levêque and D. Paugy, "Le paradox de Darwin," Recherche, vol. 402, pp. 48-51, 2006.

[13] J. L. Baglinière and G. Maisse, La truite: biologie et écologie, Inra editions, Paris, France, 1991.

[14] J. Lazard and C. Levêque, "Introduction et transferts d'espèces de poissons d'eau douce," Cahier Agriculture, vol. 18, pp. 157-163, 2009.

[15] K. A. McColl, B. D. Cooke, and A. Sunarto, "Viral biocontrol of invasive vertebrates: Lessons from the past applied to cyprinid herpesvirus-3 and carp (Cyprinus carpio) control in Australia," Biological Control, vol. 72, pp. 109-117, 2014.

[16] V. Louca, M. C. Lucas, C. Green, S. Majambere, U. Fillinger, and S. W. Lindsay, "Role of fish as predators of mosquito larvae on the floodplain of the Gambia River," Journal of Medical Entomology, vol. 46, no. 3, pp. 546-556, 2009.

[17] R. Slooteweg, "Proposed introduction of Astatoreochromis alluandi, an East African mollusccrushing cichlid, as a mean of snail control," Ann Mus R Afr Centrale sci Zool, pp. 61-64, 1989.

[18] A. Adite, K. O. Winemiller, and E. D. Fiogbe, "Ontogenetic, seasonal, and spatial variation in the diet of Heterotis niloticus (Osteoglossiformes: Osteoglossidae) in the Sô River and Lake Hlan, Benin, West Africa," Environmental Biology of Fishes, vol. 73, no. 4, pp. 367-378, 2005.

[19] F. Glasser, L'influence des facteurs externes sur la reproduction de la carpe herbivore (Ctenopharyngodon idella) en zone tropicale: une approche descriptive et expérimentale, Université de Rennes, 2003.

[20] B. R. Ellender, O. L. F. Weyl, H. Winker, H. Stelzhammer, and G. R. L. Traas, "Estimating angling effort and participation in a multi-user, inland fishery in South Africa," Fisheries Management and Ecology, vol. 17, no. 1, pp. 19-27, 2010.

[21] J. McCafferty, B. Ellender, O. Weyl, and P. Britz, "The use of water resources for inland fisheries in South Africa," Water SA, vol. 38, no. 2, 2012.

[22] B. W. Van Wilgen, V. C. Moran, and J. H. Hoffmann, "Some perspectives on the risks and benefits of biological control of invasive alien plants in the management of natural ecosystems," Journal of Environmental Management, vol. 52, no. 3, pp. 531$540,2013$.

[23] P. B. Satia and M. D. Bartley, "Introductions of Aquatic Organisms in Africa," FAO Aquaculture Newsletter, vol. 17, 1997, http://www.fao.org/docrep/005/w7611e/W761le14.htm.

[24] J. L. M. Stiassny, G. G. Teugels, and C. D. Hopkins, Poissons d'eaux douces et saumâtres de basse Guinée, Ouest de l'Afrique Centrale, Vol. 1, In faune et flore tropicales, Paris, IRD Editions, Tervureen, 2007, MRAC. 805p. 
[25] R. E. Brummett, Indigenous species for African aquaculture development, Paper presented to the World Aquaculture Society Annual Meeting, 1-5 May 2000, Nice, France http:// www.oceansatlas.com/world_fisheries_and_aquaculture/html/ resources/aqua/introspec/exoticspecies.htm.

[26] J. J. Breine, D. Nguenga, G. G. Teugels, and F. Ollevier, "A comparative study on the effect of stocking density and feeding regime on the growth rate of Tilapia cameronensis and Oreochromis niloticus (Cichlidae) in fishculture in Cameroon," Aquatic Living Resources, vol. 9, no. 1, pp. 51-56, 1996.

[27] J. Folack, E. C. Gabche, and Y. G. Chiambeng, "Fish culture potential and biodiversity conservation in the Cameroon coastal zone," in Biodiversity and sustainable use of fish in the coastal zone, E. K. Abban, C. M. V. Casal, T. M. Falk, and R. S. V. Pullin, Eds., vol. 63, pp. 44-47, ICIARM ConE Proc, 71 edition, 2000.

[28] D. Nguenga, G. G. Teugels, and F. Ollevier, "Fertilization, hatching, survival and growth rates reciprocal crosses of two strains of an African catfish Heterobranchus longifilis Valenciennes, 1840 under controlled hatchery conditions," Aquaculture Research, vol. 31, no. 7, pp. 565-573, 2000.

[29] K. Tiogue, D. Nguenga, M. Tomedi, and J. Tchoumboue, "Quelques performances reproductives et taux de survie de deux souches du poisson-chat africain Clarias gariepinus (Burchell, 1822) et de leurs croisés à Koupa-Matapit," International Journal of Biological and Chemical Sciences, vol. 2, no. 4, pp. 469-477, 2009.

[30] J. Tekwombuo, Effect of stocking ratio of Parachanna obscura as pradator and Oreochromis niloticus as prey on pond production, Faculty of Agronomy and Agricultural Sciences, Department of Animal Productions, the University of Dschang, Cameroun, 2009.

[31] "World Fish Center Conference Proceedings Number," in Proceedings of a Workshop on the Development of a Genetic Improvement Program for African catfish Clarias gariepinus, R. W. Ponzoni and H. N. Nguyen, Eds., The WorldFish Center, Penang, Malaysia, 1889.

[32] S. E. Monentcham, Alimentation et nutrition des juvéniles de Heterotis niloticus (Arapaimidae, Teleostei): premières estimations des besoins nutritionnels et valorisation des sousproduits végétaux. Thèse de doctorat. Facultés Universitaires Notre Dame de la Paix, Namur, Belgique, 2009.

[33] D. Depierre and J. Vivien, Une réussite du Service Forestier : L'introduction d'Heterotis niloticus dans le Nyong. Rev. Bois et Forêts des Tropiques, 173: 59-68, 1977.

[34] J. C. Olivry, Fleuves et rivières du Cameroun. Collections. Monographies Hydrologiques, MESRES-ORSTOM, Ed., vol. 2, 9 edition, 1986, $733 \mathrm{p}$.

[35] T. C. Tiogué, D. Nguenga, J. Tekwombuo, and G. Tekou, "Intestine morphometrics and feeding habits of the African carp. Labeobarbus batesii (Cyprinidae, Teleostei) in the the Mbô Floodplain Rivers," Journal of Biology and Nature, vol. 3, no. 1, pp. 1-9, 2015, http://www.ikpress.org.

[36] E. D. Le Cren, "The length-weight relationship and seasonal cycle in gonad weight and condition in the perch (Perca fluviatilis)," Journal of Animal Ecology, vol. 20, no. 2, pp. 201-219, 1951.

[37] R. Froese, "Cube law, condition factor and weight-length relationships: history, meta-analysis and recommendations," Journal of Applied Ichthyology, vol. 22, no. 4, pp. 241-253, 2006.
[38] R. R. Sokal and F. J. Rohlf, Biometry: the principles and practice of statistics in biological research, W.H. Freeman, New York, USA, 1995, 887 p.

[39] R. E. Brummett, "Freshwater fish seed resources in Cameroon," in Assessment of freshwater fish seed resources for sustainable aquaculture, M. G. Bondad-Reantaso, Ed., pp. 171-183, FAO Fisheries Technical Paper, Rome, Italy, 2007, No. 501. FAO. 2007. $628 \mathrm{p}$.

[40] M. Chenje and J. Mohamed-Katerere, Invasive alien species. Water Programme/South Africa, Africa Environment Outlook 2, Our Environment, Our Wealth, Section 3, Emerging Challenges, Chapter 10, 2003.

[41] T. Shipton, D. Tweddle, and M. Watts, "Introduction of the Nile Tilapia (Oreochromis niloticus) into the Eastern Cape," A report for the Eastern Cape Development Corporation, ECDC, 2008, 30pp.

[42] http://www.aquaticcommunity.com/tilapia/Oreochromis-niloticus.php, 2016.

[43] C. Levêque, "Out of Africa: the success story of tilapias," Environ. Biol. Fish, vol. 64, pp. 461-464, 2002.

[44] T. C. Tiogué, P. Zango, T. E. Efolé et al., Monthly Frequency Occurrence, Sex-ratio, Length-weight Relationship and Condition Factor of Native Fishes Caught in a Tropical Floodplain Rivers of Cameroon, Central Africa. Journal of Scientific Research \&amp; Reports 3(22): 2864-2874, 2014 http://www sciencedomain.org.

[45] O. O. Komolafe, G. A. O. Arawomo, E. O. Idowu, and A. A. Adedeji, "Status and economic impact of the fisheries of Osinmo Reservoir, Ejigbo, Nigeria," Ife Journal of Science, vol. 16, no. 2, 2014.

[46] B. O. Offem, Y. Akegbejo-Samsons, and I. T. Omoniyi, "Aspects of ecology of Clarias anguillaris (Teleostei: Clariidae) in the Cross River, Nigeria," Turkish Journal of Fisheries and Aquatic Sciences, vol. 10, no. 1, pp. 101-110, 2010.

[47] S. Eagderi and A. Radkhah, Length-weight relationship and condition factor of Mosquitofish (Gambusia holbrooki) in three inland basins of Iran. Poec Res 5 (1):39-43, (2015) http:// www.pr.bioflux.com.ro/.

[48] B. O. Offem, Y. Akegbejo-Samsons, and I. T. Omoniyi, "Biological assessment of Oreochromis niloticus (Pisces: Cichlidae; Linne, 1958) in a tropical floodplain river," African Journal of Biotechnology, vol. 6, no. 16, pp. 1966-1971, 2007.

[49] M. Faradonbeh, S. Eagderi, and F. Ghojoghi, Length-weight relationship and condition factor of seven fish species of Totkabon River (southern Caspian Sea basin), Guilan, Iran. International Journal of Aquatic Biology 3(3): 172-176, 2015.

[50] E. Montchowui, M. Kogbeto, and P. Laleye, "Weight-length relationships for commercial fish species caught in Lake Hlan in Benin (West Africa)," International Journal of Biological and Chemical Sciences, vol. 3, no. 3, pp. 612-616, 2009.

[51] O. B. Offem, Y. Akegbejo-Samsons, and I. T. Omoniyi, "Lengthweight relationship, condition factor and Sex Ratio of Forty six Important Fishes in a Tropical Flood River. Research Journal of Fisheries and Hydrobiology 4 (2): 65-72, 2009".

[52] N. Coulibaly, "Relation longueur-poids chez quatre espèces de poissons de la rivière Sourou," International Journal of Biological and Chemical Sciences, vol. 2, no. 3, 2008.

[53] Aliko N. G. G., K. S. Da Costa, Y. M. Dietoa, A. Ouattara, and G. Gourène, Caractéristiques de la population de Distichodus rostratus Günter, 1864 (pisces : Distichodontidae) du lac de barrage de Taabo (bassin du Bandama, Côte d'Ivoire). Implications 
pour une gestion rationnelle du stock. Tropicultura 28 (1): 5056, 2010.

[54] R. Ogutu-Ohwayo, "The decline of the native fishes of lakes Victoria and Kyoga (East Africa) and the impact of introduced species, especially the Nile perch, Lates niloticus, and the Nile tilapia, Oreochromis niloticus," Environmental Biology of Fishes, vol. 27, no. 2, pp. 81-96, 1990.

[55] N. C. Ujjania, M. P. S. Kohli, and L. L. Sharma, "Length-weight relationship and condition factors of Indian major carps (C. catla, L. rohita and C. mrigala) in Mahi Bajaj Sagar," Research Journal of Biology, vol. 2, no. 1, pp. 30-36, 2012, India.

[56] I. S. T. Vicente and C. E. Fonseca-Alves, "Impact of introduced Nile tilapia (Oreochromis niloticus) on non-native aquatic ecosystems," Pakistan Journal of Biological Sciences, vol. 16, no. 3, pp. 121-126, 2013.

[57] B. R. Ellender and O. L. F. Weyl, "A review of current knowledge, risk and ecological impacts associated with non-native freshwater fish introductions in South Africa," Aquatic Invasions, vol. 9, no. 2, pp. 117-132, 2014.

[58] B. R. Ellender, D. J. Woodford, O. L. F. Weyl, and I. G. Cowx, "Managing conflicts arising from fisheries enhancements based on non-native fishes in southern Africa," Journal of Fish Biology, vol. 85, no. 6, pp. 1890-1906, 2014.

[59] O. L. F. Weyl, B. R. Ellender, R. J. Wasserman, and D. J. Woodford, "Unintended consequences of using alien fish for human benefit in protected areas," Koedoe, vol. 57, no. 1, 2015. 


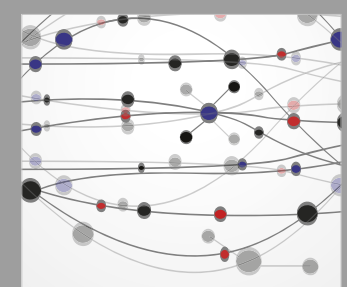

The Scientific World Journal
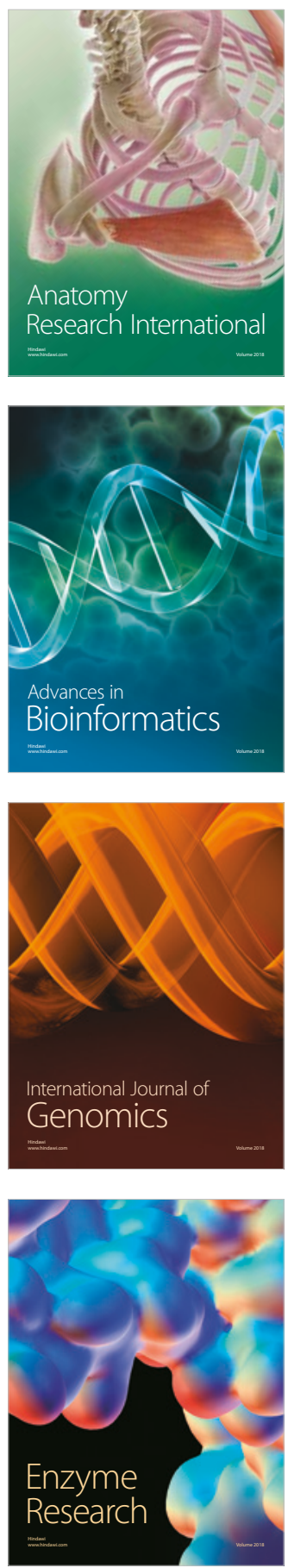
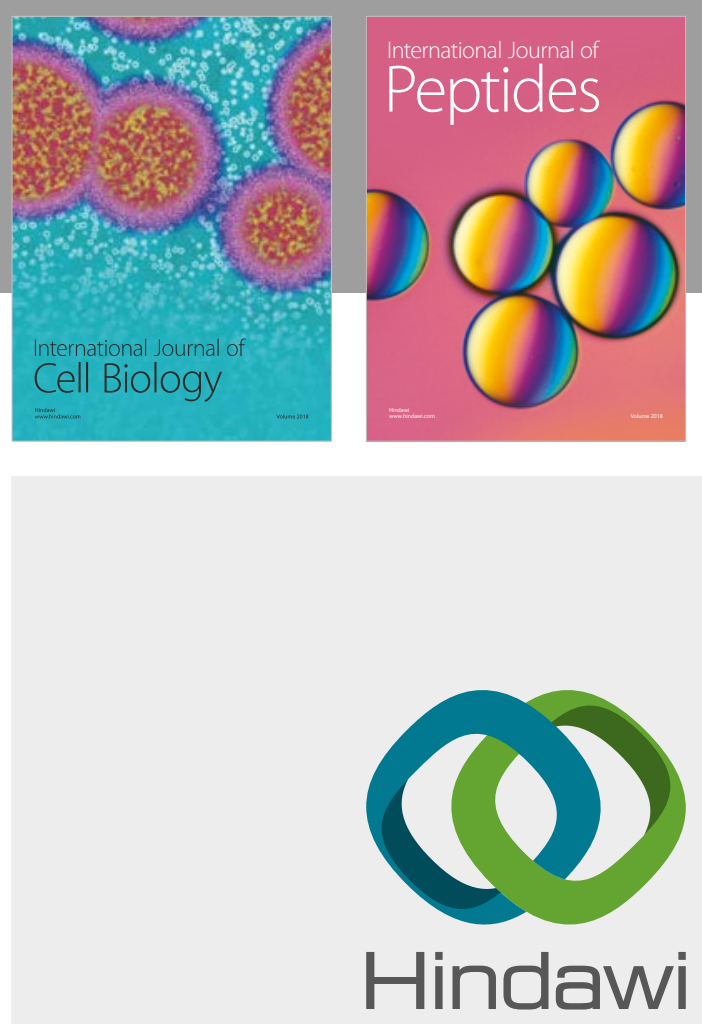

Submit your manuscripts at

www.hindawi.com
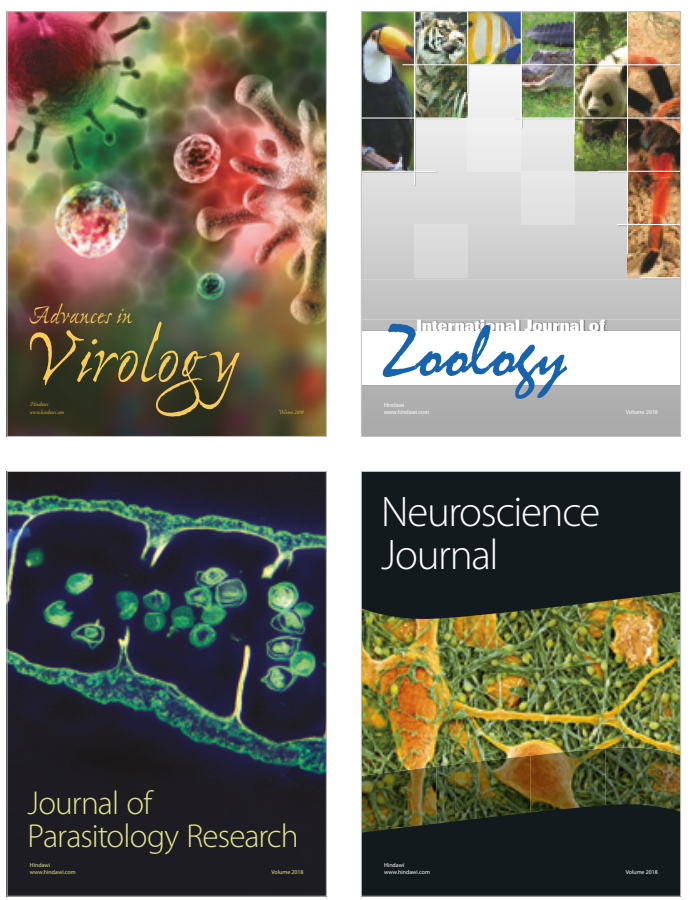
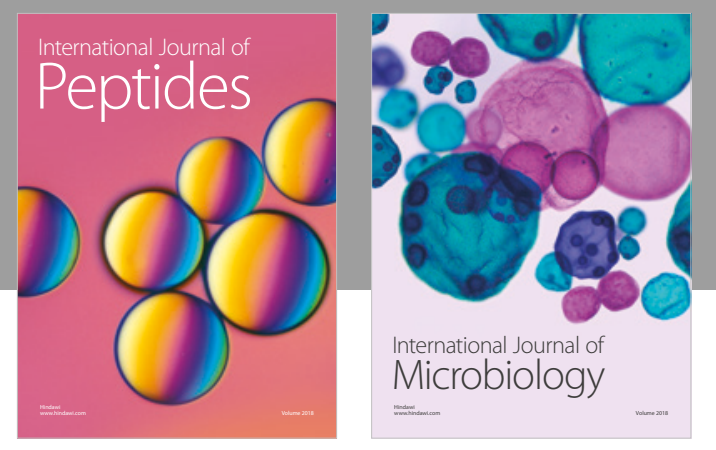

nternational Journal of Microbiology
Journal of
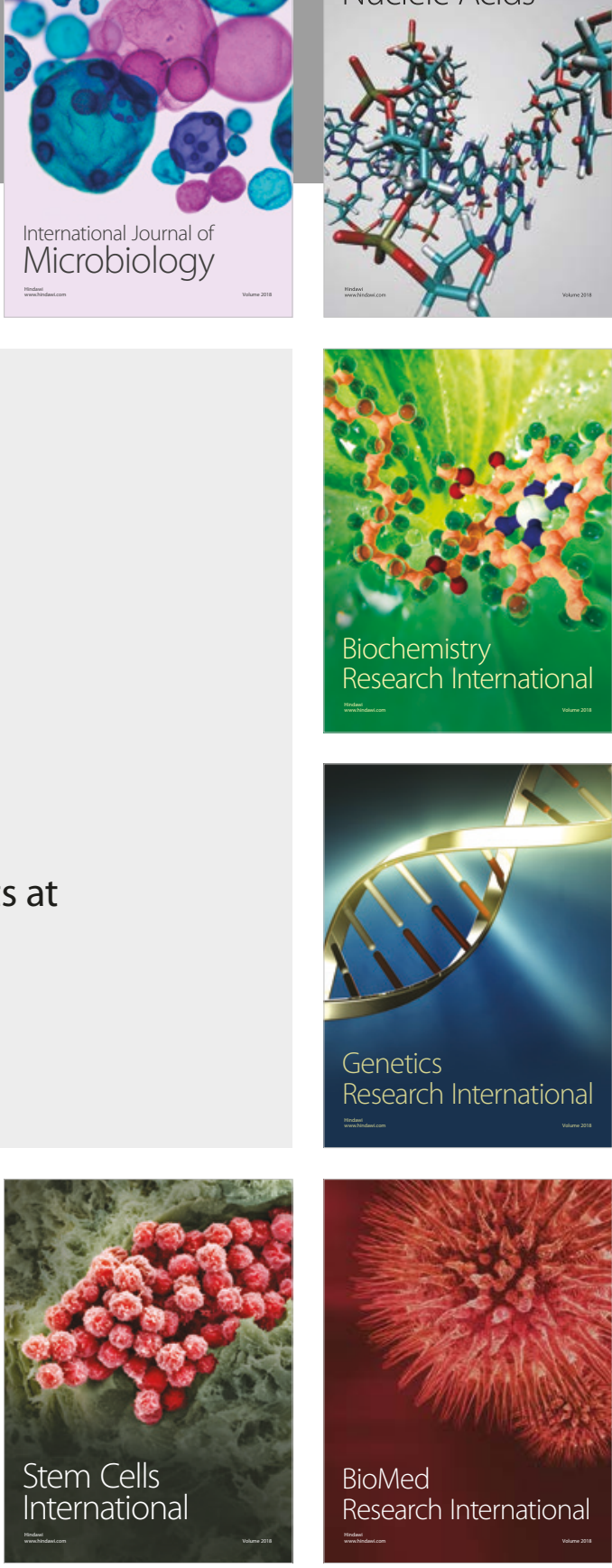
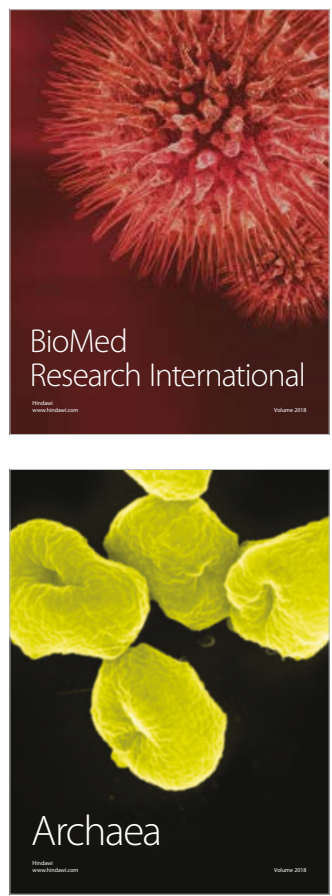